\title{
The Development of Smart Hospital Masterplan for Teaching Hospital
}

\author{
Ariani Dwi Wulandari ${ }^{1}$, Almira Filiazsanti ${ }^{2}$, Khakim Ghozali ${ }^{3}$, I Ketut Eddy Purnama ${ }^{4}$
}

\begin{abstract}
In the digital and intelligent era, all organization including hospital should transform their bussiness process from manual and paper-based activities to automatic and paperless one to become a so-called Smart Hospital. However, the development of IT services in hospital are considered not optimal due to the absence of guidelines and a foundation in its implementation. This guideline of Smart Hospital Master Plan will be the basis for implementing the concept of smart hospitals, which in practice will manage health services based on Information Technology. Furthermore, this Smart Hospital Master Plan approach applies the COBIT 5 framework to obtain guaranteed value and benefits of smart hospital implementation at the hospital. Three main activities in COBIT 5 that will use in assessing IT support for improving the quality of health services in this teaching hospital, namely evaluation, direction, and supervision.
\end{abstract}

Keywords_Master Plan TI; Smart Hospital; COBIT 5.

\section{INTRODUCTION}

The role of technology in various activities of human life has reached the simplest level. In the world of health research related to information technology has strengthened. Hospital as one of the health facilities that is responsible for public health in a country, is obliged to provide services as much as possible in order to achieve a prosperous country. The rapid developing issue of smart hospital as a concept of improving health services by utilizing the internet and technology[1] it needs to be balanced with the maturity of preparation for the implementation. The variety of resources involved in the process of implementing smart hospitals will require the management agility in preparing and managing the concepts to be applied.

The release of Presidential Regulation Number 95 in 2018 concerning electronic-based government system[2] indirectly provides support for smart hospital applications in all hospitals in Indonesia. Preparation for implementation that needs to be considered at the beginning is the preparation of a master plan carefully. All services owned by the hospital must be the main

\footnotetext{
${ }^{1}$ Ariani Dwi Wulandari is with Departement of Information System, Institut Teknologi Sepuluh Nopember, Surabaya, 60111, Indonesia. Email:ariani15@mhs.is.its.ac.id

${ }^{2}$ Almira Filiazsanti is with Departement of Information System, Institut Teknologi Sepuluh Nopember, Surabaya, 60111, Indonesia. Email: almira15@mhs.is.its.ac.id

${ }^{3}$ Khakim Ghozali Purnama is with Departement of Information Technology, Institut Teknologi Sepuluh Nopember, Surabaya, 60111, Indonesia. E-mail: khakim@is.its.ac.id

${ }^{4}$ I Ketut Eddy Purnama is with Departement of Computer Engineering, Institut Teknologi Sepuluh Nopember, Surabaya, 60111,
} Indonesia. E-mail: ketut@ee.its.ac.id focus, both internal and external services. Both are the crucial things that determine the successful way of smart hospital implementation. Maintaining and improving the quality of hospital services are the challenge for the management[3] to achieve the existing vision and goals and to be able to compete on a broader scale.

A master plan will be prepared after the agreement between the parties in management for the smart hospitals implementation that must be in line with the hospital strategy in the future. The preparation of the master plan will involve various levels of employees in the hospital to obtain accurate information and in accordance with needs.

COBIT released their latest version in 2012[4], a framework that has been widely used by practitioners in developing the principles of Information Technology (IT) governance. How a hospital is able to build a basic concept of smart hospital that is relevant to organizational conditions and various factors that influence it, is based on an analysis of existing conditions whose results will be adjusted to the basic principles of COBIT 5 implementation with the implications to maintain the hospital's cultural values. This research was conducted to produce a hospital master plan that can be implemented in a teaching hospital with various considerations that have been made. The purpose of writing this paper is to be able to develop IT in accordance with the operational needs of the teaching hospitals, to create an effective information technology in hospitals about managing data and cutting operational costs, as well as providing convenience for all employees who are interested in data accessibility.

The research results presented in this paper will be divided into several sections, 1. Introduction, 2. Methodology, 3. Results and further research discussions, and 4. Conclusions.

\section{METHOD}

Preparation of the master plan in the preimplementation stage of smart hospital needs to consider the current condition of the hospital. The strategies that chosen to produce the optimal implementation of the smart hospital master plan are user optimization strategies, IT service strategies, data and system integrity strategies, and resource management strategies.

Overview of this study at Figure 1. shows that there are 3 major stages in the preparation of the smart hospital masterplan. Various resource factors involved, resulted in management from all fields cooperating with each other in this process. 


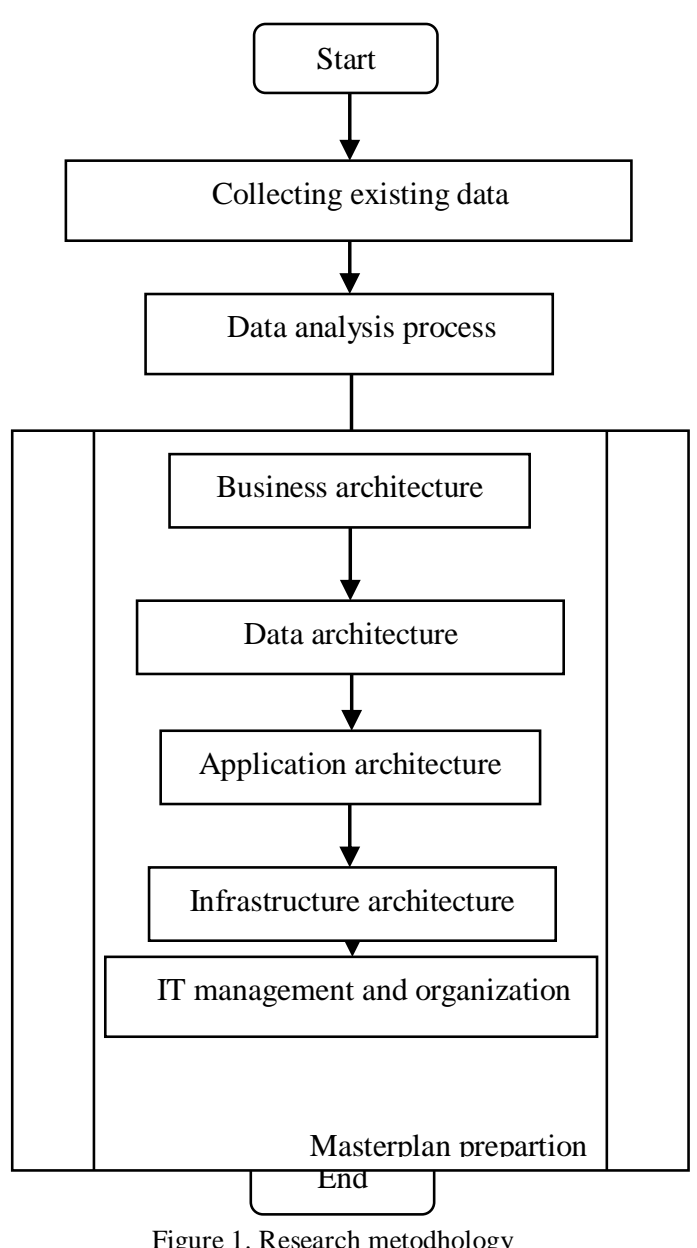

Business processes, data / information, applications, infrastructure, management and organizational conditions, and existing IT planning will be input to obtain a gap between the condition of the hospital and an ideal smart hospital concept. Furthermore, the preparation of the smart hospital master plan will be adjusted based on the results of the gap analysis and optimal implementation of the smart hospital.

\section{A. Collecting Existing Data}

The process of collecting data from the existing condition of the hospital is carried out by a number of relevant methods to obtain information that is feasible for this project.

(1) The review document is conducted to find out various limitations and knowledge related to IT development in teaching hospitals. All documents obtained are utilized according to their needs during the process of preparing the architecture of the Smart Hospital Master Plan.

(2) Group discussion which was attended by several survey teams, project management parties, and hospital stakeholders in order to obtain information about the views and desires of management from the project preparation of the master hospital smart hospital.

(3) Interviewing and filling questionnaires are conducted to obtain more accurate data from each individual due to more intense time to collect the required data.

\section{B. Data Analysis Process}

The data analysis process is based on documents / data that have been obtained in the previous stage to determine the gap between existing conditions and the ideal conditions of a smart hospital.

\section{Architecture Preparation}

The education-based smart hospital master plan consists of 4 main parts[5]. Business architecture, data and information architecture, application architecture, infrastructure architecture, and IT management and organization. The five must be interrelated so that the smart hospital master plan is in accordance with the business basis of the teaching hospital without eliminating the discrepancies found in the analysis of the existing conditions of the hospital.

The final stage of preparing the smart hospital master hospital plan is funding. The results of the calculation of the construction costs are very important for management to consider the quality of smart hospitals that want to be created in the teaching hospital environment that will not be discussed in this study.

\section{RESULTS AND DISCUSSION}

\section{A. The Result of Collecting Existing Data}

Some documents that are needed to find out how the business processes run at teaching hospitals are organizational strategic planning documents, organizational tasks and functions documents, Business Requirement Specification (BRS) documents, and hospital operational standard documents.

From the several FGD activities carried out, the perspective of the concept of the smart hospital that will be built is in accordance with the actual concept. So that the preparation of the smart hospital master plan can be continued to balance the hospital strategy going forward.

The results of the distribution of questionnaires to several hospital employees will influence the management planning and IT organization discussed in the next section.

\section{B. Analysis Results}

TABLE 1. GAP PROSES BISNIS ORGANISASI

\begin{tabular}{|c|c|c|c|}
\hline No. & Instalation & Problems & Ideal Conditions \\
\hline 1. & $\begin{array}{l}\text { Instalasi Rawat } \\
\text { Jalan, Instalasi } \\
\text { Rekam Medis, } \\
\text { Instalasi Radiologi }\end{array}$ & $\begin{array}{l}\text { The medical record } \\
\text { data is not neat }\end{array}$ & $\begin{array}{l}\text { Integration of } \\
\text { medical record } \\
\text { data }\end{array}$ \\
\hline 2. & $\begin{array}{l}\text { Instalasi } \\
\text { Radiologi, } \\
\text { Instalasi Gawat } \\
\text { Darurat, } \\
\text { Kepegawaian }\end{array}$ & $\begin{array}{l}\text { There is no } \\
\text { documentation of } \\
\text { the work results of } \\
\text { hospital employees }\end{array}$ & $\begin{array}{l}\text { There are } \\
\text { applications that } \\
\text { are able to assess } \\
\text { and measure the } \\
\text { work of hospital } \\
\text { employees }\end{array}$ \\
\hline 3. & Instalasi Gizi & $\begin{array}{l}\text { Miscommunication } \\
\text { of patient } \\
\text { nutritional needs } \\
\text { data }\end{array}$ & $\begin{array}{l}\text { There is an } \\
\text { application to } \\
\text { manage the } \\
\text { nutritional needs } \\
\text { of inpatients }\end{array}$ \\
\hline 4. & $\begin{array}{l}\text { Instalasi Rawat } \\
\text { Jalan, Instalasi }\end{array}$ & $\begin{array}{l}\text { The results of } \\
\text { ECG, x-ray, }\end{array}$ & $\begin{array}{l}\text { Storage in } \\
\text { database and use }\end{array}$ \\
\hline
\end{tabular}


The $1^{\text {st }}$ International Conference on Global Development - ICODEV

November $19^{\text {th }}, 2019$, Rectorate Building, ITS Campus, Sukolilo, Surabaya, Indonesia

\begin{tabular}{lll}
$\begin{array}{l}\text { Radiologi, } \\
\text { Instalasi } \\
\begin{array}{l}\text { Laboratorium, } \\
\text { Forensik }\end{array}\end{array}$ & $\begin{array}{l}\text { ultrasound, and } \\
\text { others are not } \\
\text { recorded digitally }\end{array}$ & $\begin{array}{l}\text { of Electronic } \\
\text { Medical Report } \\
\text { (EMR) }\end{array}$ \\
$\begin{array}{l}\text { Pendidikan dan } \\
\text { Pelatihan, } \\
\text { Kepegawaian }\end{array}$ & $\begin{array}{l}\text { The development } \\
\text { of employee skills } \\
\text { and general } \\
\text { training facilities is } \\
\text { not given enough } \\
\text { attention }\end{array}$ & $\begin{array}{l}\text { Better training } \\
\text { management }\end{array}$ \\
& \\
\hline
\end{tabular}

TABLE 2. PEMETAAN BISNIS-KEBUTUHAN INFORMASI

\begin{tabular}{|c|c|}
\hline Hospital's Program Code & Required Information \\
\hline $\begin{array}{l}\text { Service delivery with national \& } \\
\text { international standards }\end{array}$ & $\begin{array}{l}\text { Number of health services } \\
\text { available at the hospital } \\
\text { Budget to support service } \\
\text { activities } \\
\text { Percentage of national \& } \\
\text { international best-service } \\
\text { service activities } \\
\text { Percentage of patients who } \\
\text { were served well } \\
\text { List of community services } \\
\text { supported by a medical scan }\end{array}$ \\
\hline Improvement of Health Services & $\begin{array}{l}\text { Planning health service } \\
\text { activities } \\
\text { Percentage of service speed } \\
\text { from year to year } \\
\text { Number of services with good } \\
\text { feedback from patients } \\
\text { The budget spent in improving } \\
\text { services }\end{array}$ \\
\hline Service monitoring and evaluation & $\begin{array}{l}\text { Report on the implementation } \\
\text { of services from each hospital } \\
\text { service installation } \\
\text { List of activities carried out } \\
\text { while monitoring } \\
\text { Service evaluation report }\end{array}$ \\
\hline $\begin{array}{l}\text { Organization of educational } \\
\text { activities }\end{array}$ & $\begin{array}{l}\text { Number of education } \\
\text { participants } \\
\text { List of types of education } \\
\text { provided } \\
\text { Budget spent on educational } \\
\text { activities } \\
\text { List of names of presenters for } \\
\text { educational activities }\end{array}$ \\
\hline $\begin{array}{l}\text { Implementation of resource } \\
\text { training activities }\end{array}$ & $\begin{array}{l}\text { Number of trainees } \\
\text { List of training that has been } \\
\text { carried out } \\
\text { Percentage of hospital HR } \\
\text { who participated in the } \\
\text { training } \\
\text { Report on the implementation } \\
\text { of training activities } \\
\text { Material for training }\end{array}$ \\
\hline $\begin{array}{l}\text { Conducting research in the field of } \\
\text { medicine and health }\end{array}$ & $\begin{array}{l}\text { Budget spent on training } \\
\text { activities } \\
\text { List of previous research } \\
\text { topics } \\
\text { Percentage of hospital HR } \\
\text { conducting research activities } \\
\text { Budget spent on research } \\
\text { activities } \\
\text { Research report }\end{array}$ \\
\hline $\begin{array}{l}\text { Provision of completeness of } \\
\text { facilities and infrastructure } \\
\text { Maintenance of facilities and } \\
\text { infrastructure }\end{array}$ & $\begin{array}{l}\text { Provision of completeness of } \\
\text { facilities and infrastructure } \\
\text { Maintenance of facilities and } \\
\text { infrastructure }\end{array}$ \\
\hline
\end{tabular}

Organization of stakeholder activities

Hospital's Program Code
Compilation of planning
documents
Reports compilation on the
implementation results of the
program plan
Preparation of financial
management reports

Organization of collaborative activities with other PTN

\author{
Required Information \\ Compilation of planning \\ documents \\ Compilation of reports on the \\ results of the implementation \\ of the program plan \\ Preparation of financial \\ management reports
}

Number of other PTN collaboration activities that have been carried out Budget issued for other PTN cooperation activities

Other PTN names that have collaborated with the hospital Number of stakeholder collaboration activities that have been carried out List of stakeholders owned by RS

Types of collaborative activities carried out Budget issued for stakeholder collaboration activities

From the overall data collection process carried out, the analysis process is carried out so as to produce a mapping of business process gaps in Table 1., information categorization in Table 2., application gap analysis in Figure 3., and analysis of the results of questionnaire streamers by hospital employees. Some problems that can be concluded are:

1. There is no specific policy regarding management and IT organization

2. The SIMRS module has not been developed optimally

3. The fulfillment of IT needs is still handled by the procurement department, so there are IT needs fully met 4. Knowledge about the workload of IT installations is not yet understood comprehensively, so that complaints that come in sometimes do not fit into the areas of the IT workload

5. The number of HR in the IT installation section has not been able to meet the needs of the hospital

6. Lack of HR knowledge related to renewable IT needs

\section{Masterplan Smart Hospital}

A teaching hospital in this era certainly has a system that supports existing operational processes. This system not only fulfills the hospital's internal targets, but also results in satisfaction with health and education services for all identified customers. Considering the adequate number of human resources and the need to improve the image of the hospital, this research was made with the hope of achieving every hospital goal with a strong foundation and in accordance with the results of the analysis of existing business processes, information and applications.

The success of business processes is closely related to the good relations of information communication between elements in the hospital. As in Table 2., each business process in a hospital generates information needs that are used by multiuser / fields. The results of this information analysis will bring up various 
opportunities for developing smart hospital applications or systems and technologies in teaching hospitals. Information that is considered in developing applications that fit the needs of smart hospitals includes information that is accessed by internal and external parties of the hospital. The summary of information accessed by the two parties is illustrated in Figure 2. The proposed application and technology will be built in accordance with the grouping of information.

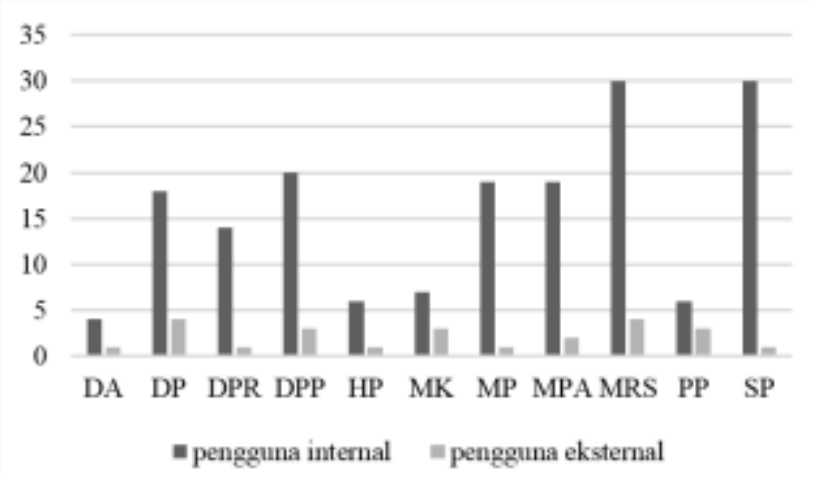

Where:

DA (Archive Documents)

DP (Reporting Documents)

DPR (Planning Documents)

DPP (Application Documents)

HP (Check Up Results)

MK (Financial Management)

MP (Service Management)

MPA (Patient Management)

MRS (Hospital Quality)

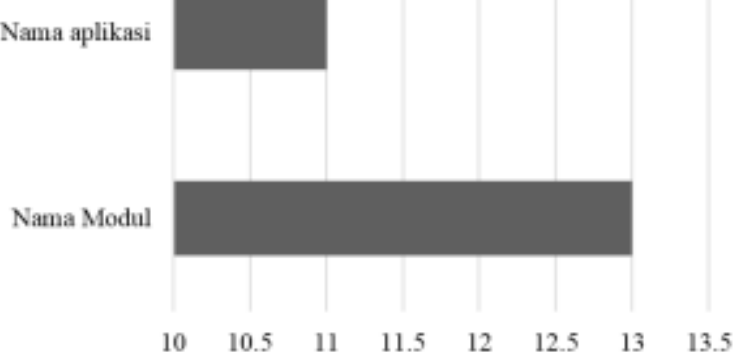

Figure 3. Application analysis gap

TABLE 3. TARGET PENGEMBANGAN APLIKASI

\section{Year 2020}

SIMRS - Modul Kasir (General Cashier, Kasir IGD, Kasir Rajal RSU,

Kasir Rawat Inap, Kasir Farmasi)

SIMRS - Modul Pendaftaran Pasien

Aplikasi Antrian Poli

SIMRS - Modul Radiologi

SIMRS - EMR

SIMRS - Modul PACS Radiologi

SIMRS - Modul Penunjang (Lab PA, Lab PK, VK, Farmasi, Operasi RSU, Hemodialisa)

SIMRS - Modul Bridging L.I.S Lab PK dengan SIM RS

SIMRS - Modul Instalasi Kedokteran Forensik (IKF)

SIMRS - Modul Gizi

\section{Year 2021}

SIMRS - Modul Lapor

Pengembangan website RS. Universitas Airlangga

SIMRS - Modul Clinical Pathway

SIMRS - Modul Kamar (Kamar Tidur dan Kamar Mayat)
SIMRS - Modul Keuangan (Laporan, Account Payable dan Forecast)

SIMRS - Modul Monitoring Program

SIMRS - Modul Bedah

SIMRS - Modul Gaji (Pengembangan)

Year 2022

SIM Pegawai

SIMRS - Modul Ambulance 118

Aplikasi RS. Universitas Airlangga berbasis mobile

SIMRS - Modul Remunerasi

SIM RS - Modul Monitoring Pegawai

SIMRS - Modul Monev Medik

SIMRS - Modul Rujukan

SIMRS - Modul Sarpras Medik

SIMRS - Modul Catalog

SIMRS - Modul Surveilans (Epidemologi)

SIMRS - Modul Pelayanan Operasi

SIMRS - Modul Pendidikan dan Penelitian

SIM RS - Modul Arsip

SIMRS - Modul Sarpras Medik

\section{Year 2024}

SIM PPID (Pejabat Pengelola Informasi dan Dokumentasi)

SIM TNDE (Tata Naskah Dinas Elektronik)

SIMRS - Modul Perpustakaan

SIM Persuratan

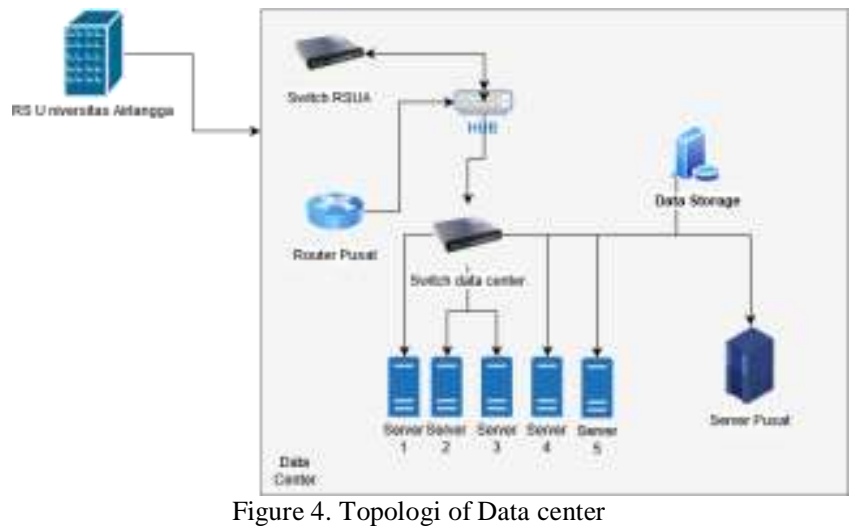

Seeing the many opportunities for system and technology development to be carried out, the implementation of smart hospitals also needs to pay attention to the capabilities of existing hospital infrastructure. Changes in floor plans and placement may also have an effect, but not to the extent that is discussed in this paper. Infrastructure planning includes network infrastructure in accordance with the location plan of the current teaching hospital. The plan to develop technology infrastructure to meet the needs of smart hospitals must be regulated as effectively as possible in order to obtain the actual technological goals and reduce operational workloads in terms of various aspects. Figure 4. above is one of the data center topology designs to meet the availability of data in smart hospital implementation operations. The application of smart hospitals that indirectly forces data integration at all levels of the organization, data center development topology is very important to be managed. And the location of the right data center will also facilitate the maintenance process going forward.

In order to guarantee the management of smart hospital technology that has been planned during 
development to its implementation, it is necessary to make regulations and policies regarding IT management. The development of IT management will be based on the COBIT 5 framework which has 4 main IT processes[4], which are:

1. Conformity, Planning and Arrangement

2. Development, Procurement and Implementation

3. Submission, Service and Support

4. Supervision, Evaluation and Assessment

In the continuous development of IT, COBIT 5 regulates several main processes related to IT governance, namely Evaluation, Direction and Supervision of the implementation and development of ICT. So the satit home needs to make standard operational rules and procedures related to the IT process to complete the above process. The proposed IT management then aims to optimize the performance of IT installations in teaching hospitals. Starting from the preparation of IT organizational structure models in teaching hospitals as shown in Figure 5. and proceed with adjusting the main tasks and functions of each position. The description of the type of work that will be charged to IT installation employees is described in Table 3.

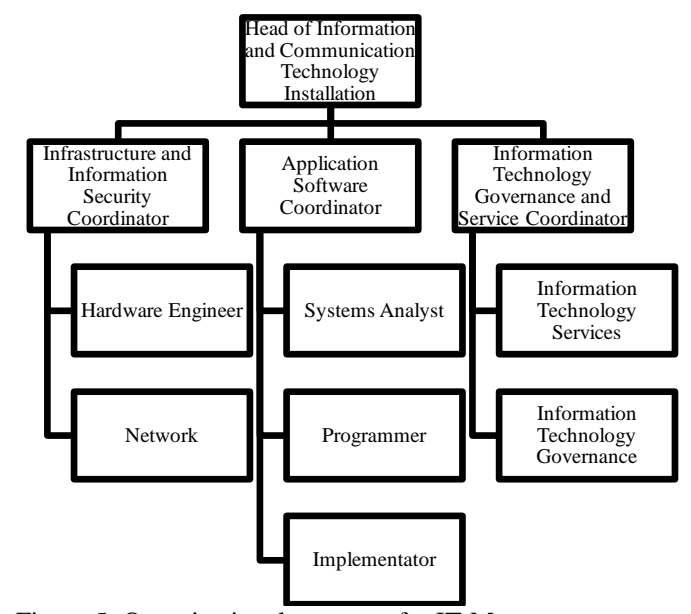

Figure 5. Organisational structure for IT Management

TABLE 4. PEMBAGIAN JENIS PEKERJAAN BIDANG TI

\begin{tabular}{ll}
\hline \hline \multicolumn{1}{c}{ Work Category } & \multicolumn{1}{c}{ Type of Work } \\
\hline Training & $\begin{array}{l}\text { Training on using SIMRS modules } \\
\text { (development results) } \\
\text { Participate in certification }\end{array}$ \\
&
\end{tabular}

HR Management Latest technology training Reduction of HR in the financial department

Adding staff to IT installations

Hospital organizational structure update. Airlangga University

Regulations and Policies

Hospital IT master plan development Compilation of regulations and policies related to IT security in terms of devices, systems and users $\begin{array}{ll}\text { The level of understanding } & \begin{array}{l}\text { Promulgation of new regulations and } \\ \text { policies }\end{array}\end{array}$

Tele-monitoring, tele-medicine, telehealt socialization

Promulgation of presidential regulation no. 95 of 2018 concerning ElectronicBased Government Systems

Monitoring and Evaluation Monitoring and Evaluation of IT regularly
The implementation process that has been proposed to build a smart hospital environment should also consider the readiness of all existing elements at various levels. The development of this master plan should be continued to optimize the implementation plan for the master hospital smart hospital teaching hospital. As for the results of the questionnaire that has been collected with the amount deemed not to represent the results of the survey because the taking of the number of respondents was not done with detailed statistical calculations. So that the addition of the number of respondents conducted not far from this research is still considered relevant to obtain more accurate information and data related to the condition of $\mathrm{HR}$ to the implementation of smart hospitals in the place where he works.

\section{CONCLUSION}

The results of this study are one of the referral options in developing a teaching hospital to improve the type to be achieved. A smart hospital implementation with the complexity of various factors will be better prepared when there is a master plan that focuses on developing hospital technology. An assessment of the organization's existing conditions must be considered in order to obtain analysis results and a master plan that is appropriate for teaching hospitals. Starting with the preparation of business architecture, data / information architecture, application architecture, infrastructure architecture, and IT management and organization.

\section{ACKNOWLEDGMENT}

We would like to thank LPPM ITS for the services that have been provided to conduct research and social activities for the ITS environment.

\section{REFERENCES}

[1] ENISA, Smart Hospitals: Security and Resilience for Smart Health Service and Infrastructures, no. November. 2017.

[2] Presiden Republik Indonesia, "Perpres 95 tahun 2018 tentang Sistem Pemerintahan Berbasis Elektronik," p. Nomor 95 Tahun 2018, 2018.

[3] G. A. Lawrence and T. G. Frater, "Implementing Change In Organisations - A Study on Limiting Factors for Managers in the Service industry," 2017.

[4] I. W. I. Org, Enabling Processes. 2012.

[5] R. Eksekutif, "| Master Plan Smart Hospital Rumah Sakit Universitas Airlangga Tahun 2020 - 2024.” 